\title{
A Natural Ethics of Gratitude
}

\author{
William M. O'Meara*
}

\begin{abstract}
Cicero has affirmed that gratitude "is not only the greatest of virtues but the parent of them all" (Pro Plancio, \#80). This paper will argue against Kant's defense of the second formulation of the categorical imperative by attempting to show that no rational argument can prove the basic principle of morality but that it is a deeply felt and profound choice of the central value of the dignity of person both in one's own life and the lives of all others. Then, following Cicero, this paper will explore how we can find a deeply felt and profound choice of gratitude at the center of the virtues of faith, hope and love. The paper is not arguing that everyone must find gratitude at the heart of faith, hope, and love, but that it is possible to do so. Next, this paper will examine how gratitude can be found at the center of the virtues of practical reason, courage, temperance, and justice. The paper is not arguing that everyone must find gratitude at the heart of practical reason, courage, temperance, and justice, but that it is possible to do so. Finally, this paper will reflect with Augustine and Aquinas on the centrality of the virtue of love in all other virtues and on how love leads to gratitude.
\end{abstract}

\section{Evaluation of Kant's Defense of the Categorical Imperative}

In his defense of the second formulation of the categorical imperative, the Formula of Humanity as an End-in-Itself, Kant argues that there must be some ultimate end worth being chosen for its own sake because otherwise all actions would simply be means chosen to ends which themselves would be means and so on into infinity and restlessness. He lectures as follows:

That the existence of something must be an end in itself, and not all things can be merely means, is just as necessary in the system of ends as Ens a se is in the existence of efficient causes. A thing that is an end in itself is a Bonum a se. What can be considered merely a means has its value as a means only when it is used as such. There must be therefore a being that is an end in itself. A thing in nature is a means for another; that goes on forever, and it is necessary at last to think of a thing that is itself an end, otherwise the series would come to no conclusion. ${ }^{1}$

Kant's presupposition of humanity as the Bonum a se, as "the ultimate purpose of creation here on earth," itself depends upon the assumption of human freedom as the condition which makes moral obligation possible. But Kant himself insists that freedom of the will is a noumenal presupposition which he himself cannot demonstrate. Korsgaard emphasizes that Kant reveals a central point of his ethics in the practical postulates of immortality, freedom

*Professor of Philosophy, James Madison University, USA.

1. Immanuel Kant, Kant's Natural Right, read in the winter semester year of 1784, Gottfried Feyerabend, trans. Lars Vinx (October 2003), 4-5. Retrieved from https://bit.ly/2NHgDh5. 
of the will, and the existence of God, and "it is primarily your own freedom that you are licensed to believe in ... ."2

Kant has assumed three points, (1) a teleological description of the plant, animal, and human kingdoms, which culminates (2) in human beings having the absolute moral purpose of realizing the value of humanity as an end in itself, which itself assumes (3) the noumenal freedom of our human will. However, all three points can be challenged.

First, a teleological description of nature in physics, chemistry, and biology is not a presupposition of these sciences. There are billions of galaxies with billions of stars, and the chance occurrence of a star with a planet with temperate climate and water which can by chance evolve living forms may be simply a fortuitous occurrence. Furthermore, from the viewpoint of evolutionary biologists there is no necessity that the human species had to evolve, but it may be our lucky accident that our specific species evolved from pre-existing species of homo.

Second, the assumption of human beings as having the absolute moral purpose of realizing the value of humanity as an end in itself is itself, as Kant tells us, "a moral principle [which] is nothing but a dimly conceived metaphysics, which is inherent in every man's rational constitution."3 Such a dimly conceived metaphysics can be challenged by those deeply affected by the absurdity of life in the $20^{\text {th }}$ and $21^{\text {st }}$ centuries. As Camus argues, "At a certain point. On his path the absurd man is tempted. History is not lacking in either religions or prophets, even without gods. He is asked to leap. All he can reply is that he doesn't fully understand, that it is not obvious."4

Furthermore, even Kant's own adoption of a teleological perspective on nature, plants, animals, and humans, is, he points out, not a constitutive metaphysics of things in themselves, "but only ... a regulative principle of the cognitive faculty." 5 However, as Guyer emphasizes for Kant, "By seeing our freedom as the ultimate end of nature, we can give ourselves a dignity that we lack as mere organisms of nature, or elevate ourselves above nature, but nature itself cannot force us to dignify ourselves in this way, nor can any theoretical proposition about nature force us to see ourselves in this way."6

2. Christine M. Korsgaard, Creating the Kingdom of Ends (New York: Cambridge University Press, 1996), 174.

3. Immanuel Kant, The Metaphysical Principles of Virtue (1797), trans. James Ellington, in Immanuel Kant: Ethical Philosophy (VI) (Indianapolis: Hackett Publishing, 1983), 376.

4. Albert Camus, The Myth of Sisyphus, and Other Essays, trans. Justin O'Brien (New York: Vintage Books, 1991), 52-53.

5. Immanuel Kant, Critique of Judgment (1790), trans. J. H. Bernard (New York: Hafner Library of Classics, 1951), 5: 197.

6. Paul Guyer, Kant on Freedom, Law, and Happiness (Cambridge: Cambridge University Press, 2000), 169. 
This affirmation of human dignity is precisely a choice, a choice which the absurd person may accept, but it is not compelled by evidence.

Indeed, the person who has accepted absurdity can easily reject Kant's argument that there must be a Bonum a se since otherwise there would be only means to further means. There is nothing absurd in a series of efficient causes there goes on in regression endlessly, as Kant himself has argued about the phenomenal world; we do not have to conclude to an Ens a se as the Uncaused Cause of a series of efficient causes. So also, we do not have to conclude to a Bonum a se because all things chosen as ends could also be chosen as means to further ends and further means even though the human heart would ever be restless in seeking new goals which would never finally satisfy human desire. We might very well wish that all action is ultimately for a Bonum a se, specifically, in human freedom, but there is no proof of human freedom.

Third, Kant's assumption of the noumenal freedom of our human will can be challenged. Whereas Kant has attempted to root absolute morality in human rationality and freedom alone, other philosophers such as David Hume have attempted to root morality precisely in human feeling without the assumption of noumenal freedom of the will. Such empirical attempts of Hume and others to emphasize human feelings can make better sense out of such cases as this:

Rachel Bachner-Melman, a clinical psychologist at Hadassah University Medical Center in Jerusalem who specializes in eating disorders, has seen the impact of extreme selflessness on the anorexic young women who populate her ward.

"They are terribly sensitive to the needs of those around them," she said in an interview. "They know who needs to be pushed in a wheelchair, who needs a word of encouragement, who needs to be fed."

Yet the spectral empaths will express no desires of their own. "They try to hide their needs or deny their needs or pretend their needs don't exist," Dr. BachnerMelman went on. "They barely feel they have the right to exist themselves." They apologize for themselves, for the hated, hollow self, by giving, ceaselessly giving. ${ }^{7}$

Reasoning alone seems insufficient to reestablish a deep sense of value in their own value. Such spectral empaths need rather a deep feeling for and/or a profound existential choice of the value of their own selves. If correct reasoning were enough to establish this deep value, then mere conversation with them would be sufficient to convince them rationally of the value of themselves. For just as they value other humans so highly in their deep empathy for others, so also they logically should value a deep empathy for themselves. However, mere logical conversation cannot heal this disease of

7. Natalie Angier, "The Pathological Altruist Gives Till Someone Hurts," The New York Times (October 3, 2011). Retrieved from https://nyti.ms/2NE5XzK. 
feeling. They must learn experientially to feel for themselves as they feel for others Such a genuine feeling of the value of both oneself and others is essential for a general morality that would embrace all humans, the Humean would argue.

If reasoning alone cannot transform such people, then either such transformation can occur only through feeling or through existential choice or through both. Either such transformation can be found in the deepest feelings for the value both of self and all other rational agents which deeply felt emotional therapy may help a person recover, or such transformation can occur both with the feeling for and profound existential choice of the value both of self and all other rational agents Kant's defense of the Formula of Humanity as an End in Itself needs to be supplemented either with the empiricist's deep usage of human feelings as a key source of human morality and/or with the existentialist's profound choice of the value of self and others as ends in themselves.

\section{The Choice of Gratitude at the Center of the Virtues of Faith, Hope and Love}

The theologian, Richard McBrien, has identified three models of ethics that have influenced Christian ethics, the teleological model of Aristotle, the deontological model of Kant, and the personalism model of Catholic moral theology through most of the $20^{\text {th }}$ and $21^{\text {st }}$ century. H. Richard Niebuhr has a famous description of the personalism model of ethics in his book, The Responsible Self, in which he explores and evaluates the teleological model, the deontological model, and the kathekontogical model of ethics. He defends this last model of ethics as superior to the other two. We will follow Niebuhr and McBrien in exploring the personalism, that is, the kathekontological model, and also use McBrien's point that recent moral theologians have gone beyond the traditional distinction between the theological virtues of faith, hope and love by which we relate to God and the cardinal virtues of wisdom, courage, temperance and fortitude by which we relate to humanity. Some theologians have adopted a distinction between general virtues, such as faith, hope and love, applicable in all our moral life and special virtues, such as a good sense of humor, applicable only in some aspects of our life.

When we are born, we do not have any general or specific virtues well developed that form our character, but we learn good actions and consequent good habits primarily, Aristotle points out, from others. ${ }^{8}$ This paper argues

8. Aristotle, The Nicomachean Ethics, trans. David Ross; revised with an intro. and notes Lesley Brown (Oxford, New York: Oxford University Press, 2009). 
that we develop our general virtues of faith, hope and love through a three step process:

(a)Faith: (i) A Gracious Gift from Others: Others first teach me to believe in my own self-worth, most especially in the power of my own understanding of the world and others and in the efficacy of my own will to be creative. (ii) Hard Work by Myself and A Gracious Gift from Myself: As a high school student, as a college student, as a person striving for excellence in my own field of study, I choose to believe in the efficacy of my own intellect and my own creative will even when I encounter teachers who do not understand me or appreciate me. (iii) A Gracious Gift for Others: I choose to believe in the power of the intellect of my students and in the efficacy of their own creative wills.

(b)Hope: (i) A Gracious Gift from Others: Others first teach me to hope in my future and our mutual future. When I do not see a future for myself, when I am all knotted-up in my own failures and my own despair, others trust in me, helping me to envision a new future and encouraging me to work for that new future. (ii) Hard Work by Myself and A Gracious Gift from Myself: Even when I may have fallen into despair, even so, something deep within me may rise up and teach me to see a new future, to hope for that new vision, and to work for that. (iii) A Gracious Gift for Others: Even though others may be trapped in profound despair or depression, I choose to believe in the power of the intellect of others and in the efficacy of their own creative wills.

(c) Love: (i) A Gracious Gift from Others: Others first teach me to love myself and others, to affirm the dignity of self and others, and to forgive myself and others when we fail. (ii) Hard Work by Myself and A Gracious Gift from Myself: Even when I fail myself and others, I can love myself, forgive myself, and start anew. (iii) A Gracious Gift for Others: I choose to treasure others, to forgive them, and to affirm their worth as persons.

\section{The Choice of Gratitude at the Center of the Virtues of Practical Wisdom, Courage, Temperance, and Justice}

(a) Practical Wisdom: (i) A Gracious Gift from Others: Others first teach me to learn practical wisdom, for example, in avoiding the profound mistake of trying to be perfect (perfectionism, often with an accompanying inability to forgive self and others). They teach me The Middle Way, The Golden Mean, helping me to avoid the extremes both of too much certitude and of too little confidence in my own intellect. Also, they teach me to avoid both the rigidity of a perfectionist effort at morality and of a lackadaisical effort in my 
moral endeavors. Morality is meant to be much more an art of living for positive values, not a rigid science of avoiding what is wrong. (ii) Hard Work by Myself and A Gracious Gift from Myself: Even though I may misinterpret morality as an attempt to be perfect and even though I may fail in my moral endeavors, I can from deep within myself learn to correct my moral failures, to forgive myself, and to reconceive moral life as the art of living for generous love, hope, and faith. Even though others may judge me harshly for my failures, I can choose from deep within to renew myself. (iii) Gracious Gift for Others: As others have taught me the value of practical wisdom in the adventurous art of creating goodness in self and others, so also I can do the same for others who may learn from me.

(b) Courage: (i) A Gracious Gift from Others: Others first teach me to be courageous, for example, against discrimination by risking myself to affirm the dignity of others, and, for another example, in forgiving myself and others when we fail. A few years ago, I reflected on the fact that I have been born into a long line of my human ancestors, my parents, my grandparents, my great grandparents, and back into centuries of my ancestors, and I realized that these women and men had risked themselves courageously hundreds of times, gracing me with their courage. I was deeply grateful. (ii) Hard Work by Myself and A Gracious Gift from Myself: Even when I face great dangers, I can summon my strength to be courageous and to act boldly for my values. (iii) A Gracious Gift for Others: My courage can be a Gracious Gift for others as when I taught my children to climb trees with me.

(c) Temperance: (i) A Gracious Gift from Others: Others first teach me to be temperate in fulfilling my desires and, especially, in the interweaving of sibling rivalry to moderate my desires and competitiveness to involve all in the family into the fulfillment of the essential desires of all. (ii) Hard Work by Myself and A Gracious Gift from Myself: Even when I fail myself and others through overindulgence, I can choose to be temperate and to start anew. (iii) A Gracious Gift for Others: My temperance which comes from my generous love of others and of self can be an exemplar for others, teaching them the values of sharing and of inclusiveness.

(d) Justice: (i) A Gracious Gift from Others: Others first teach me fairness and justice which enable me to learn the dignity of self and others. For example, the history of America as a story of expanding justice for all can teach us to be truly generous with our use of medical resources so that we have true and fair health care for all in our country. (ii) Hard Work by Myself and A Gracious Gift from Myself: Even when I fail myself and others through unjust actions, I can love myself, forgive myself, and start anew with renewed actions of justice. (iii) A Gracious 
Gift for Others: I choose through a rich sense of expanding justice to treasure others, to forgive them, and to affirm their worth as persons and to re-involve them in a community of forgiveness.

\section{Commentary on Love at the Heart of All Virtues by Augustine and Aquinas}

Augustine offers us a vision of Christlike love as the heart and soul of the four cardinal virtues:

So that temperance is love, keeping the self entire and uncorrupt for the beloved. Courage is love, bearing everything gladly for the sake of the beloved. Righteousness [justice] is love serving the beloved only, and therefore ruling well. And prudence is love, wisely discerning what helps it and what hinders it" (Augustine, footnote 20). ${ }^{9}$

Although we can think of temperance as a virtue devoted unto proper care of one's body and its appetites, we can also think of temperance as a way of loving oneself for the sake of loving others. For the sake of love and though love, a person is temperate in one' s actions and appetites for the sake of the beloved. Although we can think of courage as a wise way of responding to dangers and obstacles threatening to oneself, we can also think of courage as a way of sustaining one's moral purpose of love for the sake of the beloved when both self and others are undergoing threat and danger. Although we can think of justice as the wise way of protecting self and others from harm to their basic human dignity, we can also think of justice as the habit of affirming, enhancing, and enriching the human dignity of the beloved, thereby ruling well for the sake of the others governed. Finally, although we can understand practical wisdom as a virtue of responding thoughtfully to all the needs of self and others, we can understand this thoughtful response as the response of love, as the response of deep and true caring for self and others.

We can understand, then, Augustine as offering an addition to Aristotle's famous definition of virtue: "Virtue, then, is a state of character concerned with choice, lying in a mean, i.e. the mean relative to us, this being determined by a rational principle, and by that principle by which the man of practical wisdom would determine it." 10 Augustine is accepting the whole definition, adding to the ending phrase: "by that principle by which the man of practical wisdom and generous love would determine it."

9. Bernhard Haring, Free and Faithful in Christ: Moral Theology for Clergy and Laity Volumes I and II (New York: The Crossroad Publishing Company, 1982), 41.

10. Aristotle, The Nicomachean Ethics. 
Although both Augustine and Aquinas are quite rightly to be understood as offering us a religious ethics rooted in God's love, they understand this rootedness as first in the order of being, that is, as coming from the origin of love, God, who has created all. However, as this paper has defended, they clearly hold that we first need to experience being loved generously by others in the order of learning before we can conceptualize or experience God's generous love for humanity.

Bernhard Haring, a $20^{\text {th }}$ century Catholic moral theologian, offers us the commentary from Augustine and Aquinas on 1 John, chapter 4:

16 We have come to know and to believe in the love God has for us. God is love, and whoever remains in love remains in God and God in him.

17 In this is love brought to perfection among us, that we have confidence on the day of judgment because as he is, so are we in this world.

18 There is no fear in love, but perfect love drives out fear because fear has to do with punishment, and so one who fears is not yet perfect in love.

19 We love because he first loved us.

20 If anyone says, "I love God," but hates his brother, he is a liar; for whoever does not love a brother whom he has seen cannot love God whom he has not seen.

21 This is the commandment we have from him: whoever loves God must also love his brother [1 Jn 4:16-21].

Verse 19 clearly says that people can love because God loved people first. And I always then read verse 20 as saying that there was a contradiction between claiming to love God and failing to love one's brother. That understanding is surely correct.

However, Bernhard Haring has added what may be an even richer understanding of the verse 20. He notes that Aquinas calls this love referred to in verse 19, which God first gives, the ontological priority of God's love. God's love is the creative source which enables people to love. However, in the psychological priority of how we learn to love, both Augustine and Aquinas say that there must first be in our human learning some experience of true love of neighbor before we can love the invisible God. The great psychologist, St. Augustine, is quite clear on this:

The love of God is first in the order of precept but the love of brother is the first in the order of action. ... Love, therefore, your neighbor, and look into yourself to see where this love of neighbor comes from. There you will see God insofar as you are capable. Begin, therefore, by loving your neighbour, share your bread with the hungry, open your house to the roofless, clothe the naked and despise no one of the same human race (Augustine, Tract. XVII in Jo. Ev.6ff, PL35, 1531). ${ }^{11}$

11. Haring, Free and Faithful in Christ:, 427. 
Thomas Aquinas is equally clear: "In the order of perfection and dignity, love of God comes first before love of neighbor. But in the order of origin and disposition, love of neighbor precedes the act of loving God" (Summa Theologica I II, $q 68$, a 8 ad 2). ${ }^{12}$

\section{Conclusion}

In the analysis of this paper, we have found a three-fold process in the virtues generally and also especially in the virtues of love and practical wisdom. In this three-fold process of Love, (1) we are first loved by others who guide us into proper self-love and proper love of others. (2) Then we work at developing proper self-love and at times even give unto our self a gift of self-love. (3) Finally, as we have received generous love from others, we can now give the same unto others.

So also, in a similar three-fold process of practical wisdom, (1) we can first receive a gift of wisdom from others who teach us to avoid the mistake of trying to be perfect, avoiding perfectionism which is so often accompanied with an inability to forgive self and others. (2) Then we work at developing morality as meant to be much more an art of living for positive values, not a rigid science of avoiding what is wrong. Also, even though others may judge me harshly for my failures, I can choose from deep within to renew myself. (3) Finally, as others have taught me the value of practical wisdom in the adventurous art of creating goodness in self and others, so also I can do the same for others who may learn from me.

Since others have graced us by the gift of their generous love and practical wisdom and since generous love and practical wisdom are the heart and soul of the practice of all the moral virtues for Augustine and Aquinas, we can choose to live all of our moral lives in gratitude to others for their love and practical wisdom. It is true that a person can choose to live morality as a series of obligations both to others and to oneself, especially if morality has been taught to that person as a series of harsh commands and punishments. However, it is possible to transcend the moral life as series of obligations whose breaking would require appropriate punishments whether severe or light. It is possible to choose to live from the more profound motive of gratitude in agreement with Cicero who has affirmed that gratitude is not only the greatest of virtues but the parent of them all.

Confirming this approach to how gratitude may fittingly be understood as the heart of the moral life, Bernhard Haring notes how Abraham Maslow finds "in the spiritually healthy person who has had [in a]"peak experience" a

12. Ibid. 
vision of gratitude, a perception of the gift character of all life."13 Also, in a religious perspective, Haring finds Confucius seeing the best virtues as the gifts from the Tao. For Confucius writes, "The four greatest gifts heaven has bestowed on the wise people are benevolence, gentleness, justice and prudence."14 Finally, Haring understands Catholic theology as affirming that the virtuous believer: "truly open to the [Divine] Spirit sees everything in the dimension of gratuitousness and graciousness. He does not appropriate virtue to his own glory but renders thanks ... . Everything is perceived and honoured as gift ...."15

\section{Bibliography}

Angier, Natalie. "The Pathological Altruist Gives Till Someone Hurts." The New York Times (October 3, 2011). Retrieved from https://nyti.ms/2NE5XzK.

Aristotle. The Nicomachean Ethics. Translated by David Ross; Revised with an Introduction and Notes by Lesley Brown. Oxford, New York: Oxford University Press, 2009.

Camus, Albert. The Myth of Sisyphus, and Other Essays. Translated by Justin O' Brie. New York: Vintage Books, 1991.

Cicero, Marcus Tullius. The Orations of Marcus Tullius Cicero. Translated by C. D. Yonge. London: George Bell \& Sons, 1891.

Guyer, Paul. Kant on Freedom, Law, and Happiness. Cambridge: Cambridge University Press, 2000.

Haring, Bernhard. Free and Faithful in Christ: Moral Theology for Clergy and Laity Volumes I and II. New York: The Crossroad Publishing Company, 1982.

Kant, Immanuel. Kant's Natural Right. Read in the winter semester year of 1784, Gottfried Feyerabend. Translated by Lars Vinx. October 2003. Retrieved from https://bit.ly/2NHgDh5.

The Metaphysical Principles of Virtue (1797). Translated by James Ellington. In Immanuel Kant: Ethical Philosophy (VI). Indianapolis: Hackett Publishing, 1983.

_. Critique of Judgment (1790). Translated by J. H. Bernard. New York: Hafner Library of Classics, 1951.

Korsgaard, Christine M. Creating the Kingdom of Ends. New York: Cambridge University Press, 1996.

13. Ibid., 200.

14. Ibid., 201.

15. Ibid., 421. 